\title{
Supercooling and Cold Hardiness in Sour Cherry Germplasm: Vegetative Tissue
}

\author{
H.M. Mathers ${ }^{1}$ \\ Department of Horticulture and Crop Science, Ohio State University, Columbus, OH 43210-1096.
}

Additional Index words. Prunus cerasus, species distribution, differential thermal analysis (DTA), germplasm evaluation, principal component analysis

\begin{abstract}
Knowledge of the level of cold hardiness and how hardiness is inherited in sour cherry is essential to germplasm collection and cultivar development. Twig samples of two sweet cherries (Prunus avium L.), 12 sour cherries (P. cerasus L.), and one ground cherry ( $P$. fruticosa Pall.) of diverse geographic origins were collected in Jan. 1990 and monthly from Aug. 1990 to Mar. 1991, preconditioned to induce maximum cold resistance, and subjected to freeze tests and differential thermal analysis. Low temperature exotherms (LTEs) were detected in all stems of P. cerasus investigated and correlated to xylem incipient injury temperatures (ITs) from December to February $(r=0.84, P \leq 0.01)$. March had the best correlation of LTEs to xylem ITs with $r=0.84, P \leq 0.01$. LTEs were strongly correlated to phloem-cambium ITs in November, representing the acclimation period. The correlation coefficient $(r)$ for the phloem-cambium ITs and the twig LTEs during November was 0.68 , significant at $\boldsymbol{P} \leq \mathbf{0 . 0 1}$. Cortical tissue and vegetative bud injuries were not correlated to the stem LTEs. Xylem ITs were selected for evaluating the cold resistance of sour cherry in December to March and phloem-cambium ITs were selected for November. The degree of supercooling and hardiness of the phloem-cambium in late fall and early spring appears significant in determining the stem hardiness and commercial range of $P$. cerasus. Phloem-cambium tissue, expressed the most rapid deacclimation response. The average decrease in hardiness for the phloem-cambium, xylem, and cortical tissues between February and March was $4^{\circ} \mathrm{C}, 0.32{ }^{\circ} \mathrm{C}$, and $2.14{ }^{\circ} \mathrm{C}$, respectively. Principal component (PC) analyses of the phloem-cambium and cortical tissues depicted gradations between minimum survival temperatures of the two presumed progenitor species of sour cherry, i.e., sweet cherry and ground cherry. The first principal component (PC1), which accounted for $61 \%$ of the total variance, was used to separate among cultivars and seedlings. Cultivars and seedlings at the negative end of PC1 exhibited hardier phloem-cambium tissue at critical injury times, October, December, January, and March than cultivars and seedlings at the positive end of the PC1 axis. Cultivars and progeny of crosses of northern origin parents showed hardiness values more comparable to ground cherry than did selections of less-cold-hardy parents suggesting that cold is a major selective force, contributing to sour cherry population variation.
\end{abstract}

The freezing response of certain tissues can be monitored using differential thermal analysis (DTA) (Wisniewski et al., 1990). The xylem parenchyma cells of many woody plants including, Betula lenta, Carya ovata, Castanea dentata, Cercis canadensis, Cornus florida, Fagus sylvatica, Fraxinus pennsylvanica, Malus spp., Syringa vulgaris, Quercus rubra, and several Prunus species undergo deep supercooling (Quamme, 1995). The type of freezing observed by DTAs occurs in plants which resist freezing by supercooling. The DTA profile of species that undergo deep supercooling indicates two exotherms. The first is associated with bulk water freezing within lumens of tracheary elements and extracellular spaces and is called the "high temperature exotherm" (Wisniewski, 1995). The second exotherm is associated with tissues that supercool to the homogeneous nucleation temperature within living cells and is termed the "low temperature exotherm" (LTE) (Ketchie and Kammereck, 1987; Wisniewski, 1995).

Most Prunus species have the ability to maintain supercooled cellular water in their xylem ray parenchyma (Rajashekar and Burke, 1978; Wisniewski, 1995). Xylem tissues can supercool to as low as $-47^{\circ} \mathrm{C}$ before homogeneous nucleation takes place.

Received for publication 25 Mar. 2003. Accepted for publication $28 \mathrm{Apr}$. 2004. Salaries and research support were provided by state and federal funds appropriated to the Ohio Agricultural Research and Development Center, The Ohio State Univ. and Dept. of Horticulture, Michigan State Univ., East Lansing, Mich. Manuscript number HCS 02-33. I acknowledge the direction provided by A.F. Iezzoni, G.S. Howell, J. Flore, K. Poff, and C. Chong as committee members and the assistance provided by H. Quamme, J. Beaver, D. Ferree and S. Myers.

1Assistant Professor. Email address: mathers.7@osu.edu
Kovacs et al. (2002) found that loss of tissue water content lowered temperatures at which LTEs occurred in grape buds. To date, no studies have examined the general presence, occurrence and influence of the environment on LTEs in sour cherry (P. cerasus).

A diverse sour cherry germplasm collection was established at Michigan State Univ. (MSU), Clarksville Horticultural Experiment Station, Clarksville, Mich., representing plant material collected in Serbia, Romania, Hungary, Bulgaria and Poland (Hillig and Iezzoni, 1988). Because of the scope and diversity of this germplasm collection, an excellent opportunity to investigate supercooling and cold hardiness in sour cherry existed. Understanding cold resistance heritability and environmental influence in sour cherry is critical to cultivar development and future germplasm collection. The MSU collection contains a range of plant material from sweet cherry ( $P$. avium) types to ground cherry $(P$. fruticosa) types, the two putative progenitor species of $P$. cerasus (Beaver and Iezzoni, 1993). Because a lengthy quarantine period is required for imported clonal material, the collection consists primarily of hybrid and open-pollinated (o.p.) seedlings of elite selections from eastern European breeding programs (Hillig and Iezzoni, 1988).

At the whole plant level, resistance to cold is a complex quantitatively inherited character (Gelvonauskis et al., 2000). Principal Component (PC) analysis has been used successfully to understand the response of complex traits to imposed treatments or evolutionary pressures (Iezzoni and Pritts, 1991). PC analysis is a multivariate statistical technique, which generates linear combinations of the variables that contain most of their variability (Llorens et al., 2002; Rao, 1964). The PC analysis 
is intended to reveal common principles in the data. When a large number of measurements are available in the data set, PC analysis provides a reduction of the data to the variables of most interest without loss of significant information (Llorens et al., 2002; Rao, 1964; Tausz et al., 1998). When variables are highly intercorrelated (as in this study), principal component analysis can be used to separate plant material based on performance (Lo and Abrahamson, 1996).

The shape of the LTE and the temperature at which it is initiated is subject to seasonal changes (Ketchie and Kammereck, 1987) and in general follows a pattern similar to those of other processes involved in cold acclimation: increasing in the fall, reaching a maximum in midwinter, and then decreasing in the spring (Wisniewski, 1995). The basis for the complex shape of the exotherms, which is often accentuated during periods of acclimation and deacclimation (Ashworth, 1993), is not understood (Wisniewski, 1995). Xylem tissue in some species, rather than freezing homogeneously, may respond as a heterogeneous population of cells that freeze over a wide temperature range (Wisniewski, 1995) as indicated by the complex shape of the LTE.

In addition to the shape variability of LTEs, the number of LTEs can also vary (Ketchie and Kammereck, 1987). Ketchie and Kammereck (1987) observed at least three exotherms in apple, and indicated that they represent the freezing of different tissues of the stem: pith, primary xylem and secondary xylem. In many cases, researchers have established a correlation between stem tissue injury and the temperature range of the LTE, at the stage of maximum cold resistance (George et al., 1974; Ketchie and Kammereck, 1987). Hong and Sucoff (1982), in a study of eight woody plant species, observed a linear relationship between the number of dead xylem ray cells and the amount of supercooled water that had frozen. Association of the entire freezing curve with tissue injury is unclear in studies where the LTE is quite broad or exhibits several peaks. Ketchie and Kammereck (1987) observed that only during midwinter was the peak near the homogeneous nucleation point of water associated with xylem tissue injury.

The main objective of this study was to compare DTA and visual browning as methods to determine minimum hardiness levels for cherry xylem, phloem-cambium, cortex and vegetative buds. Three additional objectives were: 1 ) to determine if these methods detect differences in these tissues in the cherry germplasm from August to March; 2) to determine if the cherry selections differed in their cold resistance; and, 3) to examine the possible association of minimum survival temperatures to geographic origin.

\section{Materials and Methods}

Plant material. The plant material included two Prunus avium selections, one $P$. fruticosa selection, and $12 P$. cerasus selections. The material was chosen to represent different geographical origins (Table 1). All studies were conducted with detached shoots of the previous season's growth collected at the MSU, Clarksville Horticultural Experiment Station, Clarksville, Mich. A three-way treatment structure of cultivar, freeze temperature and month of evaluation was used in a completely randomized design with three sub-samples and four replications per treatment. The study was conducted over the period of 9 months Jan. 1990 (data not shown) and Aug. 1990 to Mar. 1991. All twigs were cut in the field and placed in polyethylene bags for transit and storage. When collections were conducted during temperatures of $0^{\circ} \mathrm{C}$ or below, the polyethylene-bagged samples were placed in ice-packed coolers to prevent tissue thawing.

ACClimation AND FReEZing TReatments. All twigs were subjected to one of two artificial hardening procedures, depending on the hardiness of the material at the time of collection (Sakai, 1982). For December through March collections, twigs were hardened at $-3{ }^{\circ} \mathrm{C}$ for 3 weeks followed by $-5{ }^{\circ} \mathrm{C}$ for 1 week and $-10{ }^{\circ} \mathrm{C}$ for $5 \mathrm{~d}$ and for August through November, 0 to -1 ${ }^{\circ} \mathrm{C}$ for a maximum of $20 \mathrm{~d}$ (Sakai, 1982). These artificial hardening treatments were used to induce maximum hardiness in order to minimize environmental variation (Gusta et al., 1997; Sakai and Weiser, 1973) and are used in woody plant cold hardiness evaluations to replace replications over years (Sakai and Weiser, 1973). After artificial hardening samples were prepared according to McKenzie and Weiser (1975) and frozen in a converted ultralow Revco freezer (Mathers et al., 1991) in two stages, a holding period at $-3{ }^{\circ} \mathrm{C}$ for $10 \mathrm{~h}$ followed by a temperature drop of $5{ }^{\circ} \mathrm{C} / \mathrm{h}$ to a series of test temperatures with the aid of a programmable temperature controller (Micron 82300; Research Inc., Minneapolis, Minn.), at five-degree intervals from -5 to -50 ${ }^{\circ} \mathrm{C}$. At each test temperature, four replicates were removed and thawed in cold storage at $0{ }^{\circ} \mathrm{C}$ for $16 \mathrm{~h}$.

VisUAL HARDINESS DETERMINATIONS. After thawing, twigs were placed in a water-saturated atmosphere for 5 to $8 \mathrm{~d}$ at $\approx 20^{\circ} \mathrm{C}$. Cross sections of twigs were examined under a dissecting microscope $(40 \times)$ and were scored numerically $(0-4)$ for injury to the cortical tissue, the phloem-cambium region and the xylem on the basis of the extent and intensity of oxidative browning (Quamme et al., 1982). A rating of 0 represented no injury, 1 a trace of injury, 2 slight injury, 3 moderate injury, and 4 represented severe injury. The vegetative buds were also cut and scored numerically for browning (0-4).

Quamme et al. (1982) defined the temperature of incipient injury as the temperature at which the average injury score did
Table 1. Names, abbreviations, presumed origins, and geographic designations of the cultivars and seedlings evaluated; o.p. indicates open pollinated.

\begin{tabular}{|c|c|c|c|}
\hline Name & Abbr. & $\begin{array}{l}\text { Presumed } \\
\text { origin }\end{array}$ & $\begin{array}{c}\text { Geographic } \\
\text { origin }\end{array}$ \\
\hline \multicolumn{4}{|l|}{ Prunus avium } \\
\hline Emperor Francis & $\mathrm{F}$ & Unknown & Southern \\
\hline Schmidt & S & Unknown & Southern \\
\hline \multicolumn{4}{|l|}{ Prunus cerasus } \\
\hline Cigany Meggy o.p. & G & Hungary & Southern \\
\hline Csengodi Csokras o.p. & $\mathrm{K}$ & Hungary & Southern \\
\hline English Morello & $\mathrm{E}$ & Germany & Northern \\
\hline English Morello X Sumadinka & $\mathrm{U}$ & Germany $X$ Serbia & Northern \\
\hline Fructbare von Michurin & V & Moldavia & Northern \\
\hline \multirow[t]{2}{*}{ Meteor } & $\mathrm{R}$ & Montmorency X & \\
\hline & & Russian Seedling & Northern \\
\hline Montmorency & M & France & Northern \\
\hline Oblacinska o.p. & $\mathrm{O}$ & Serbia & Southern \\
\hline Pandy 114 o.p. & A & Hungary & Southern \\
\hline Pitic de Iasi o.p. & I & Moldavia & Northern \\
\hline Spaniole $X$ Crisana o.p. & $\mathrm{C}$ & Spain $\mathrm{X}$ Romania & Southern \\
\hline Wolynska X Sumadinka & W & Poland X Serbia & Northern \\
\hline Prunus fruticosa 586-1 & $\mathrm{P}$ & Unknown & Northern \\
\hline
\end{tabular}


not exceed 1 using hand-fitted graphs of the injury scores. Here incipient injury was defined as the temperature at which injury did not exceed 1.0 using non-linear regression of the $0-4$ injury scores (IT). The IT values were determined graphically using PLOT-IT Non-Linear Regression function $\mathrm{Y}=\mathrm{B}(1) /(1.0+\mathrm{B}(2) * \mathrm{EXP}(-$ $\left.\mathrm{B}(3)^{*} \mathrm{X}\right)$ ) (PLOT-IT) (Scientific Programming Enterprises, Haslett, Mich., 1991). This nonlinear regression equation fits an exponential curve, where " $Y$ " is a function of the exponent of " $\mathrm{X}$ " and "B(i)" is a coefficient, "*" signifies multiple and "/" signifies divide. " $Y$ " is the dependent variable and " $\mathrm{X}$ " is the independent variable. For example, 'Meteor' xylem injury scores in February, " $\mathrm{B}(1)$ " is 18.09942, " $\mathrm{B}(2)$ " is 11052.55 and " $\mathrm{B}(3)$ " is -0.1748091 . For this curve the equation reads $\mathrm{Y}=18.09942$ / $\left(1+11052.55 * \mathrm{e}^{-(-0.1748091) * \mathrm{x}}\right)$, so that if " $\mathrm{X}$ " was $-40^{\circ} \mathrm{C}$, " $\mathrm{Y}$ " would be $18.09942 / 11.155876$ or 1.622 .

Analyses were conducted on the calculated IT means of four replicates and three subsamples per selection. Analyses of variance (ANOVAs) were conducted using SAS procedure General Linear Model (GLM), (SAS Institute, Cary, N.C). Fisher's least significance difference test was used to compare means (SAS Institute, 1989) and graphs were produced with Microsoft Excel (Microsoft Corp., 1994, Seattle, Wash.) from the analyses. IT values were rounded to the nearest $0.5^{\circ} \mathrm{C}$ (Cain and Andersen, 1976).

Differential Thermal anALYSIS. The DTA utilized an EXP16 multiplexer and amplifier, a 37 pin D male connector, a DAS 8 output board (MetraByte Corp., Taunton, Mass.) and thermoelectric modules $(15 \times 15 \mathrm{~mm})(\mathrm{CPI} 1.0-17-06 \mathrm{~L}$; Melcor Materials Electronic Products Corp., Trenton, N.J.). The EXP 16 was set for a gain of 1000-fold. The samples were affixed to each module with the aid of a thermally conductive paste (Omegatherm 201; Omega Engineering, Stamford, Conn.). The modules were wrapped with parafilm and aluminium foil. The modules were then suspended in a structural foam box within a converted ultralow freezer (model 1790D, Revco; Rheem Manufacturing Co., Asheville, N.C.) (Mathers et al., 1991). The same freeze regime was followed as for the detached twigs. The temperature was monitored with a 36-gauge copper-constantan thermocouple connected to the reference channel of the EXP 16. Four samples per cultivar or seedling were evaluated at each collection date. Analyses were conducted on the calculated LTE means of three plants per selection. ANOVAs were conducted using SAS procedure GLM. Fisher's least significant difference test was used to compare means (SAS Institute, 1989).

Comparison of DTA AND VISUAL BROWNING. Linear regression analyses were performed, where the means of the LTE were regressed on the means of IT. The coefficient of determination $\left(r^{2}\right)$ values were calculated using Microsoft Excel, ChartWizard function (Microsoft Excel, Version 5.0c). The coefficient of determination $\left(r^{2}\right)$ and correlation coefficients ( $r$ values) were calculated for the xylem, phloem-cambium, cortex and vegetative buds from November to March by calculating the square root of $r^{2}$. Significance tables were used to determine the probability levels of $r$ (Steel and Torrie, 1980).

PC AnALYsis. Principal component (PC) analysis was performed using the IT values with SAS procedure PRINCOMP (SAS Institute, 1989). A separate PC analysis was conducted for each of the four tissue types evaluated, phloem-cambium, xylem, cortical, and vegetable buds. Since PC analysis is intended to reveal common principles in the data (Tausz et al., 1998), all evaluation temperatures and replications were pooled. Factor loadings can be interpreted as correlations between the respective variables and components (Llorens et al., 2002). Table 1 lists the abbreviations of cultivars and seedlings used in the PC analyses. ITs were chosen for the PC analyses because they occurred in the four tissues types and in all 9 months evaluated, i.e., Jan. 1990 (data not shown) and Aug. 1990 to Mar. 1991. In each of the four tissue analyses, the cultivar and seedling means were used to create a correlation matrix from which standardized PC scores were extracted. To determine which of the first two PCs in each analysis accounted for the greatest portion of the variance for each month, the eigenvectors of the two PCs were compared (Currie et al., 2000). The most variation attributed by each month was determined by identifying the eigenvector with the highest absolute value for that month (Llorens et al., 2002).

\section{Results}

Comparison of DTA ANd Visual BRowning. Low temperature exotherms were present in most of the cherry selections in November (Table 2), January (Table 3), February (Table 4), and March (Table 5). The one exception was P. fruticosa, which only exhibited a LTE in February (Table 4). The size of the LTE varied among the selections but tended to be smaller in the more hardy selections. LTEs were also present in December (data not shown). LTEs were not present in any of the cherry selections from collections in August, September, or October (data not shown).

Significant differences in xylem browning among the cherry selections were only found for September (data not shown), January, (Table 3) and March (Table 5). Significant differences for phloem-cambium browning appeared in September, October (data not shown), November (Table 2), January (Table 3), and March (Table 5). Significant differences for the cortical browning were only found in January (Table 3) and March (Table 5) and for the vegetative buds only in November (Table 2) and March (Table 5). Only in March (Table 5) were there significant differences in all vegetative tissues and the twig LTEs.

There was a significant correlation $(r=0.84, P \leq 0.01)$ between oxidative browning, measured as IT, and the LTE for the xylem from December, January and February (midwinter). Xylem browning occurred within $5^{\circ} \mathrm{C}$, on average, of the LTE, and in almost every case the LTE occurred at a higher temperature than the xylem browning (Tables 3 and 4). In deacclimation, represented by the March collection, the best correlation $(r=0.96, P \leq 0.01)$ of the LTE was to the xylem browning (Table 5). Xylem browning began within $4{ }^{\circ} \mathrm{C}$, on average, of the LTE, and in every case the LTE preceded browning (Table 5).

In November, there was a significant correlation $(r=0.68, P \leq$ 0.01 ) between oxidative browning, measured as IT, and the LTE for the phloem-cambium of the cherry selections. Phloem-cambium browning occurred within $5^{\circ} \mathrm{C}$ of the LTE, and for 11 of the 14 cultivars and seedlings studied browning occurred before the LTE (Table 2), indicating the tissue was injured before the LTE occurred. The tissue by LTE interaction was nonsignificant indicating the slopes of the xylem and phloem-cambium tissues were not significantly different (data not shown). In November, only the phloem-cambium and vegetative buds revealed significant differences among cultivars and seedlings (data not shown). Cortical tissue and vegetative bud injury were not correlated to the stem LTEs, in any of the months investigated (data not shown).

RESPONSE DIFFERENCES AMONG TISSUES. The ANOVA of the IT data showed significant differences due to cultivars and seedlings, tissue and month. The interaction of cultivars and seedlings $\times$ month, cultivars and seedlings $\times$ tissue, tissue $\times$ month and 
Table 2. Comparison of a November collection of tissue types of 15 cherry cultivar/seedlings evaluated by low temperature exotherm (LTE) analysis conducted at $-5^{\circ} \mathrm{C} / \mathrm{h}$ and by visual injury of phloem-cambium, xylem, and cortical shoot sections and vegetative bud cross sections frozen to $-35^{\circ} \mathrm{C}$ at $-5^{\circ} \mathrm{C} / \mathrm{h}$ expressed as incipient injury temperature (IT).

\begin{tabular}{|c|c|c|c|c|c|}
\hline \multirow[b]{2}{*}{ Cultivar/seedling } & \multirow{2}{*}{$\frac{\mathrm{LTE}\left({ }^{\circ} \mathrm{C}\right)}{\text { Twig }}$} & \multicolumn{4}{|c|}{$\mathrm{IT}\left({ }^{\circ} \mathrm{C}\right)$} \\
\hline & & Xylem & Phloem & Cortical & $\mathrm{VB}^{\mathrm{y}}$ \\
\hline \multicolumn{6}{|l|}{ Prunus avium } \\
\hline Emperor Francis & $-22.0 \mathrm{a}^{\mathrm{z}}$ & $-23.0 \mathrm{a}$ & $-19.0 \mathrm{a}$ & $-26.0 \mathrm{a}$ & $-15.0 \mathrm{a}$ \\
\hline Schmidt & $-26.0 \mathrm{a}$ & $-26.0 \mathrm{a}$ & $-21.0 \mathrm{~b}$ & $-24.0 \mathrm{a}$ & $-17.0 \mathrm{a}$ \\
\hline \multicolumn{6}{|l|}{ Prunus cerasus } \\
\hline Csengodi Csokas & $-22.0 \mathrm{a}$ & $-25.25 \mathrm{a}$ & $-17.0 \mathrm{a}$ & $-24.0 \mathrm{a}$ & $-18.5 \mathrm{a}$ \\
\hline Spaniole $X$ Crisana & $-22.0 \mathrm{a}$ & $-18.0 \mathrm{a}$ & $-20.3 \mathrm{a}$ & $-25.3 \mathrm{a}$ & $-24.0 \mathrm{~b}$ \\
\hline Pandy 114 & $-23.0 \mathrm{a}$ & $-22.83 \mathrm{a}$ & $-22.3 b$ & $-25.67 \mathrm{a}$ & $-22.3 b$ \\
\hline Pitic de Iasi & $-25.0 \mathrm{a}$ & $-23.83 \mathrm{a}$ & $-25.0 \mathrm{~b}$ & $-25.0 \mathrm{a}$ & $-21.67 b$ \\
\hline Wolynska X Sumadinka & $-28.0 \mathrm{a}$ & $-28.3 \mathrm{a}$ & $-26.0 \mathrm{~b}$ & $-24.0 \mathrm{a}$ & $-24.3 \mathrm{~b}$ \\
\hline EMy X Sumadinka & $-25.5 \mathrm{a}$ & $-27.25 \mathrm{a}$ & $-27.5 b$ & $-19.5 \mathrm{a}$ & $-23.0 \mathrm{~b}$ \\
\hline Oblacinska & $-27.5 \mathrm{a}$ & $-27.0 \mathrm{a}$ & $-27.0 \mathrm{~b}$ & $-25.0 \mathrm{a}$ & $-25.5 b$ \\
\hline Cigany Meggy & $-25.67 \mathrm{a}$ & $-26.5 \mathrm{a}$ & $-22.3 \mathrm{~b}$ & $-25.0 \mathrm{a}$ & $-20.3 \mathrm{a}$ \\
\hline Montmorency & $-23.0 \mathrm{a}$ & $-27.0 \mathrm{a}$ & $-19.0 \mathrm{a}$ & $-26.0 \mathrm{a}$ & $-15.0 \mathrm{a}$ \\
\hline Fructbare von Michurin & $-30.0 \mathrm{a}$ & $-27.0 \mathrm{a}$ & $-27.0 \mathrm{~b}$ & $-26.0 \mathrm{a}$ & $-27.0 \mathrm{~b}$ \\
\hline English Morello & $-23.0 \mathrm{a}$ & $-11.0 \mathrm{a}$ & $-28.0 \mathrm{~b}$ & $-27.0 \mathrm{a}$ & $-25.0 \mathrm{~b}$ \\
\hline Meteor & $-27.0 \mathrm{a}$ & $-29.0 \mathrm{a}$ & $-28.0 \mathrm{~b}$ & $-28.0 \mathrm{a}$ & $-26.0 \mathrm{~b}$ \\
\hline P. fruticosa 586-1 & --- & $-20.0 \mathrm{a}$ & $-29.0 \mathrm{~b}$ & $-25.0 \mathrm{a}$ & $-22.0 \mathrm{~b}$ \\
\hline
\end{tabular}

zMeans in columns, based on three subsamples, per four replicates, followed by different letters are significantly different $(P=0.05)$ according to Fisher's least significant difference test.

yThe abbreviation EM and VB represent English Morello and vegetative buds, respectively.

Table 3. Comparison of a January collection of tissue types of 15 cherry cultivar/seedlings evaluated by low temperature exotherm (LTE) analysis conducted at $-5^{\circ} \mathrm{C} / \mathrm{h}$ and by visual injury of phloem-cambium, xylem, and cortical shoot sections and vegetative bud cross sections frozen to $-50^{\circ} \mathrm{C}$ at $-5^{\circ} \mathrm{C} / \mathrm{h}$ expressed as incipient injury temperature (IT).

\begin{tabular}{|c|c|c|c|c|c|}
\hline \multirow[b]{2}{*}{ Cultivar/seedling } & \multirow{2}{*}{$\frac{\text { LTE }\left({ }^{\circ} \mathrm{C}\right)}{\text { Twig }}$} & \multicolumn{4}{|c|}{ IT $\left({ }^{\circ} \mathrm{C}\right)$} \\
\hline & & Xylem & Phloem & Cortical & $\mathrm{VB}^{\mathrm{y}}$ \\
\hline \multicolumn{6}{|l|}{$\overline{\text { Prunus avium }}$} \\
\hline Emperor Francis & $-22.0 \mathrm{a}^{\mathrm{z}}$ & $-25.0 \mathrm{a}$ & $-16.0 \mathrm{a}$ & $-23.0 \mathrm{a}$ & $-24.0 \mathrm{a}$ \\
\hline Schmidt & $-25.0 \mathrm{a}$ & $-31.0 \mathrm{a}$ & $-15.0 \mathrm{a}$ & $-27.0 \mathrm{a}$ & $-22.0 \mathrm{a}$ \\
\hline \multicolumn{6}{|l|}{ Prunus cerasus } \\
\hline Csengodi Csokas & $-34.0 \mathrm{~b}$ & $-34.0 \mathrm{a}$ & $-27.5 \mathrm{~b}$ & $-30.5 \mathrm{a}$ & $-25.0 \mathrm{a}$ \\
\hline Spaniole X Crisana & $-36.0 \mathrm{c}$ & $-43.0 \mathrm{c}$ & $-31.3 b$ & $-36.0 \mathrm{~b}$ & $-26.3 \mathrm{a}$ \\
\hline Pandy 114 & $-40.0 \mathrm{c}$ & $-41.67 \mathrm{c}$ & $-31.0 \mathrm{~b}$ & $-35.3 b$ & $-28.3 \mathrm{a}$ \\
\hline Piticde Iasi & $-38.5 \mathrm{c}$ & $-44.3 c$ & $-31.0 \mathrm{~b}$ & $-37.3 c$ & $-24.0 \mathrm{a}$ \\
\hline Wolynska X Sumadinka & $-37.3 \mathrm{c}$ & $-43.67 \mathrm{c}$ & $-31.0 \mathrm{~b}$ & $-39.67 \mathrm{c}$ & $-30.0 \mathrm{a}$ \\
\hline EMy X Sumadinka & $-21.0 \mathrm{a}$ & $-40.0 \mathrm{c}$ & $-29.5 b$ & $-37.0 \mathrm{c}$ & $-31.0 \mathrm{a}$ \\
\hline Oblacinska & $-37.0 \mathrm{c}$ & $-43.5 \mathrm{c}$ & $-31.5 \mathrm{c}$ & $-38.0 \mathrm{c}$ & $-34.0 \mathrm{a}$ \\
\hline Cigany Meggy & --- & $-38.3 b$ & $-27.0 \mathrm{a}$ & $-34.3 b$ & $-26.67 \mathrm{a}$ \\
\hline Montmorency & $-38.0 \mathrm{c}$ & $-39.0 b$ & $-32.0 \mathrm{c}$ & $-34.0 \mathrm{~b}$ & $-28.0 \mathrm{a}$ \\
\hline Fructbare von Michurin & $-37.0 \mathrm{c}$ & $-43.0 \mathrm{c}$ & $-33.0 \mathrm{c}$ & $-40.0 \mathrm{c}$ & $-31.0 \mathrm{a}$ \\
\hline English Morello & $-41.0 \mathrm{c}$ & $-37.0 \mathrm{~b}$ & $-29.0 \mathrm{~b}$ & $-32.0 \mathrm{~b}$ & $-25.0 \mathrm{a}$ \\
\hline Meteor & $-42.0 \mathrm{c}$ & $-43.0 \mathrm{c}$ & $-33.0 \mathrm{c}$ & $-40.0 \mathrm{c}$ & $-30.0 \mathrm{a}$ \\
\hline P. fruticosa 586-1 & --- & $-45.0 \mathrm{c}$ & $-37.0 \mathrm{c}$ & $-41.0 \mathrm{c}$ & $-34.0 \mathrm{a}$ \\
\hline
\end{tabular}

zMeans in columns, based on three subsamples, per four replicates, followed by different letters are significantly different $(P=0.05)$ according to Fisher's least significant difference test.

yThe abbreviation EM and VB represent English Morello and vegetative buds, respectively.

cultivars and seedlings $\times$ plant (the mean of three plants per selection) were also significant (data not shown).

Phloem-cambium tissue was the most susceptible vegetative tissue for the least hardy taxon, $P$. avium and the cultivars and seedlings of $P$. cerasus, i.e., 'Csengodi Csokas', 'Spaniole' $\mathbf{x}$ 'Crisana', Pandy 114, 'Oblacinska', and 'Cigany Meggy.' For $P$. avium 'Schmidt', the lowest survival temperatures for the phloem-cambium tissue occurred in February (Fig. 1). The phloemcambium was strongly influenced by the warm temperatures. This was especially evident in the southern genotypes ('Schmidt', 'Csengodi Csokas', and 'Spaniole' $x$ 'Crisana'), which exhibited variable (up-and-down) patterns of hardiness over the period of August to March. The phloem-cambium, of the northern genotypes ('Wolynska' x 'Sumadinka', 'English Morello' x 'Sumadinka', 'Meteor'), was also strongly influenced by the warm temperatures experienced in late November before the December collection (ambient temperature data not shown).

Between February (Table 4) and March (Table 5), the phloem- 
Table 4. Comparison of a February collection of tissue types of 15 cherry cultivar/seedlings evaluated by low temperature exotherm (LTE) analysis conducted at $-5^{\circ} \mathrm{C} / \mathrm{h}$ and by visual injury of phloem-cambium, xylem, and cortical shoot sections and vegetative bud cross sections frozen to $-45^{\circ} \mathrm{C}$ at $-5^{\circ} \mathrm{C} / \mathrm{h}$ expressed as incipient injury temperature (IT).

\begin{tabular}{|c|c|c|c|c|c|}
\hline \multirow[b]{2}{*}{ Cultivar/seedling } & \multirow{2}{*}{$\frac{\mathrm{LTE}\left({ }^{\circ} \mathrm{C}\right)}{\text { Twig }}$} & \multicolumn{4}{|c|}{$\operatorname{IT}\left({ }^{\circ} \mathrm{C}\right)$} \\
\hline & & Xylem & Phloem & Cortical & $\mathrm{VB}^{\mathrm{y}}$ \\
\hline \multicolumn{6}{|l|}{$\overline{\text { Prunus avium }}$} \\
\hline Emperor Francis & $-25.0 \mathrm{a}^{\mathrm{z}}$ & $-28.0 \mathrm{a}$ & $-25.0 \mathrm{a}$ & $-26.0 \mathrm{a}$ & $-28.0 \mathrm{a}$ \\
\hline Schmidt & $-27.0 \mathrm{a}$ & $-34.0 \mathrm{a}$ & $-30.0 \mathrm{a}$ & $-32.0 \mathrm{a}$ & $-29.0 \mathrm{a}$ \\
\hline \multicolumn{6}{|l|}{ Prunus cerasus } \\
\hline Csengodi Csokas & $-27.5 \mathrm{a}$ & $-32.0 \mathrm{a}$ & $-20.5 \mathrm{a}$ & $-27.0 \mathrm{a}$ & $-32.5 \mathrm{a}$ \\
\hline (Spaniole X Crisana) & $-24.5 \mathrm{a}$ & $-23.67 \mathrm{a}$ & $-25.67 \mathrm{a}$ & $-26.3 \mathrm{a}$ & $-30.67 \mathrm{a}$ \\
\hline Pandy 114 & $-27.67 \mathrm{a}$ & $-31.0 \mathrm{a}$ & $-28.67 \mathrm{a}$ & $-31.3 \mathrm{a}$ & $-31.67 \mathrm{a}$ \\
\hline Pitic de Iasi & $-30.5 \mathrm{a}$ & $-34.67 \mathrm{a}$ & $-34.3 \mathrm{a}$ & $-33.0 \mathrm{a}$ & $-32.3 \mathrm{a}$ \\
\hline Wolynska X Sumadinka & $-34.0 \mathrm{a}$ & $-38.0 \mathrm{a}$ & $-32.67 \mathrm{a}$ & $-37.0 \mathrm{a}$ & $-31.0 \mathrm{a}$ \\
\hline EM y X Sumadinka & $-34.5 \mathrm{a}$ & $-36.0 \mathrm{a}$ & $-31.0 \mathrm{a}$ & $-33.5 \mathrm{a}$ & -32.0 \\
\hline Oblacinska & $-27.5 \mathrm{a}$ & $-30.0 \mathrm{a}$ & $-26.5 \mathrm{a}$ & $-30.5 \mathrm{a}$ & $-31.0 \mathrm{a}$ \\
\hline Cigany Meggy & $-32.5 \mathrm{a}$ & $-35.3 \mathrm{a}$ & $-32.0 \mathrm{a}$ & $-32.0 \mathrm{a}$ & $-31.67 \mathrm{a}$ \\
\hline Montmorency & $-33.0 \mathrm{a}$ & $-37.0 \mathrm{a}$ & $-33.0 \mathrm{a}$ & $-35.0 \mathrm{a}$ & $-31.0 \mathrm{a}$ \\
\hline Fructbare von Michurin & $-30.0 \mathrm{a}$ & $-37.0 \mathrm{a}$ & $-32.0 \mathrm{a}$ & $-35.0 \mathrm{a}$ & $-31.0 \mathrm{a}$ \\
\hline English Morello & $-25.0 \mathrm{a}$ & $-33.0 \mathrm{a}$ & $-24.0 \mathrm{a}$ & $-33.0 \mathrm{a}$ & $-30.0 \mathrm{a}$ \\
\hline Meteor & $-33.0 \mathrm{a}$ & $-37.0 \mathrm{a}$ & $-34.0 \mathrm{a}$ & $-37.0 \mathrm{a}$ & $-32.0 \mathrm{a}$ \\
\hline P. fruticosa 586-1 & $-32.0 \mathrm{a}$ & $-32.0 \mathrm{a}$ & $-30.0 \mathrm{a}$ & $-33.0 \mathrm{a}$ & $-31.0 \mathrm{a}$ \\
\hline
\end{tabular}

${ }^{2}$ Means in columns, based on three subsamples, per four replicates, followed by different letters are significantly different $(P=0.05)$ according to Fisher's least significant difference test.

yThe abbreviation EM and VB represent English Morello and vegetative buds, respectively.

Table 5. Comparison of a March collection of tissue types of 15 cherry cultivar/seedlings evaluated by low temperature exotherm (LTE) analysis conducted at $-5^{\circ} \mathrm{C} / \mathrm{h}$ and by visual injury of phloem-cambium, xylem, and cortical shoot sections and vegetative bud cross sections frozen to $-40^{\circ} \mathrm{C}$ at $-5^{\circ} \mathrm{C} / \mathrm{h}$ expressed as incipient injury temperature (IT).

\begin{tabular}{|c|c|c|c|c|c|}
\hline \multirow[b]{2}{*}{ Cultivar/seedling } & \multirow{2}{*}{$\frac{\mathrm{LTE}\left({ }^{\circ} \mathrm{C}\right)}{\text { Twig }}$} & \multicolumn{4}{|c|}{ IT $\left({ }^{\circ} \mathrm{C}\right)$} \\
\hline & & Xylem & Phloem & Cortical & $\mathrm{VB}^{\mathrm{y}}$ \\
\hline \multicolumn{6}{|l|}{$\overline{\text { Prunus avium }}$} \\
\hline Emperor Francis & $-10.0 \mathrm{a}^{\mathrm{z}}$ & $-24.0 \mathrm{a}$ & $-10.0 \mathrm{a}$ & $-19.0 \mathrm{a}$ & $-15.0 \mathrm{a}$ \\
\hline Schmidt & $-19.0 \mathrm{a}$ & $-27.0 \mathrm{a}$ & $-16.0 \mathrm{~b}$ & $-27.0 \mathrm{~b}$ & $-19.0 \mathrm{a}$ \\
\hline \multicolumn{6}{|l|}{ Prunus cerasus } \\
\hline Csengodi Csokas & $-33.0 \mathrm{~b}$ & $-34.5 b$ & $-25.0 \mathrm{c}$ & $-30.5 b$ & $-27.0 \mathrm{c}$ \\
\hline Spaniole X Crisana & --- & $-36.0 \mathrm{~b}$ & $-23.0 \mathrm{~b}$ & $-31.67 \mathrm{c}$ & $-24.67 \mathrm{~b}$ \\
\hline Pandy 114 & $-31.0 \mathrm{~b}$ & $-34.0 \mathrm{~b}$ & $-22.0 \mathrm{~b}$ & $-30.3 b$ & $-25.0 \mathrm{~b}$ \\
\hline Pitic de Iasi & $-32.5 b$ & $-34.0 \mathrm{~b}$ & $-29.0 \mathrm{c}$ & $-30.0 \mathrm{~b}$ & $-28.7 \mathrm{c}$ \\
\hline Wolynska X Sumadinka & $-31.0 \mathrm{~b}$ & $-35.0 \mathrm{~b}$ & $-29.0 \mathrm{c}$ & $-32.0 \mathrm{c}$ & $-29.67 c$ \\
\hline EMy X Sumadinka & $-32.0 \mathrm{~b}$ & $-35.0 \mathrm{~b}$ & $-30.5 \mathrm{c}$ & $-32.0 \mathrm{c}$ & $-26.5 \mathrm{c}$ \\
\hline Oblacinska & $-32.0 \mathrm{~b}$ & $-36.0 \mathrm{~b}$ & $-28.5 \mathrm{c}$ & $-32.0 \mathrm{c}$ & $-29.5 \mathrm{c}$ \\
\hline Cigany Meggy & $-27.5 b$ & $-34.67 b$ & $-26.0 \mathrm{c}$ & $-30.0 \mathrm{~b}$ & $-25.0 \mathrm{~b}$ \\
\hline Montmorency & $-32.0 b$ & $-34.0 \mathrm{~b}$ & $-23.0 \mathrm{~b}$ & $-30.0 \mathrm{~b}$ & $-24.0 \mathrm{~b}$ \\
\hline Fructbare von Michurin & $-33.0 \mathrm{~b}$ & $-37.0 \mathrm{~b}$ & $-32.0 \mathrm{c}$ & $-32.0 \mathrm{c}$ & $-23.0 \mathrm{~b}$ \\
\hline English Morello & $-31.0 \mathrm{~b}$ & $-35.0 \mathrm{~b}$ & $-26.0 \mathrm{c}$ & $-29.0 \mathrm{~b}$ & $-27.0 \mathrm{c}$ \\
\hline Meteor & $-33.0 \mathrm{~b}$ & $-35.0 \mathrm{~b}$ & $-29.0 \mathrm{c}$ & $-31.0 \mathrm{c}$ & $-31.0 \mathrm{c}$ \\
\hline P. fruticosa 586-1 & --- & $-23.0 \mathrm{a}$ & $-34.0 \mathrm{c}$ & $-33.0 \mathrm{c}$ & $-27.0 \mathrm{c}$ \\
\hline
\end{tabular}

${ }^{2}$ Means in columns, based on three subsamples, per four replicates, followed by different letters are significantly different $(P=0.05)$ according to Fisher's least significant difference test.

yThe abbreviation EM and VB represents English Morello and vegetative buds, respectively.

cambium deacclimated much more rapidly than the xylem, showing a loss in hardiness of $3.8^{\circ} \mathrm{C}$ averaged over the 15 selections vs. $0.5^{\circ} \mathrm{C}$ for the xylem. In March, the phloem was significantly less hardy than the xylem or cortex (Table 5). The average phloem hardiness was $-25.5^{\circ} \mathrm{C}$ vs. the average xylem and cortical hardiness of $-33{ }^{\circ} \mathrm{C}$ and $-30{ }^{\circ} \mathrm{C}$, respectively. The loss of hardiness of phloem tissue in March was most pronounced in the two $P$. avium cultivars and 'Montmorency', which deacclimated by 15,14 , and $10^{\circ} \mathrm{C}$, respectively, between February (Table 4) and
March (Table 5). Some of the P. cerasus seedlings, of northern origin, exhibit superior hardiness in the phloem-cambium when compared to 'Montmorency' in late fall (Table 2) and early spring (Table 5). The significant differences between northern and southern types for phloem-cambium (Fig. 1) appeared to depend on area of origin.

Phloem-cambium PC analysis. Given the complexity of the data collected over the four tissue types and 9 months of evaluation, data were subjected to PC analysis, which generates 


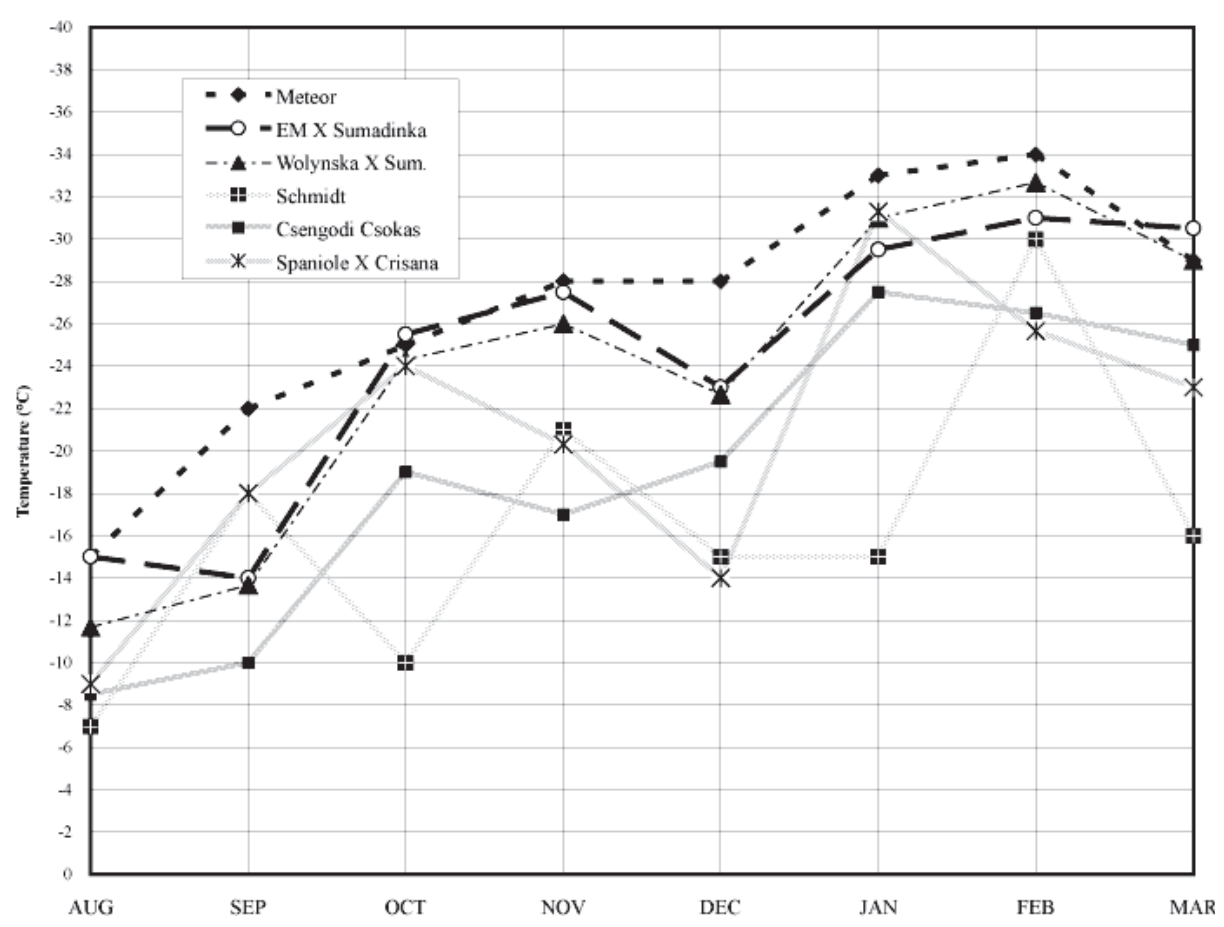

Fig. 1. Cultivar/seedling $\times$ month interaction of incipient injury temperature (IT) data of the phloem-cambium tissue, sampled from Aug. 1990 to Mar. 1991. The abbreviation EM represents English Morello.

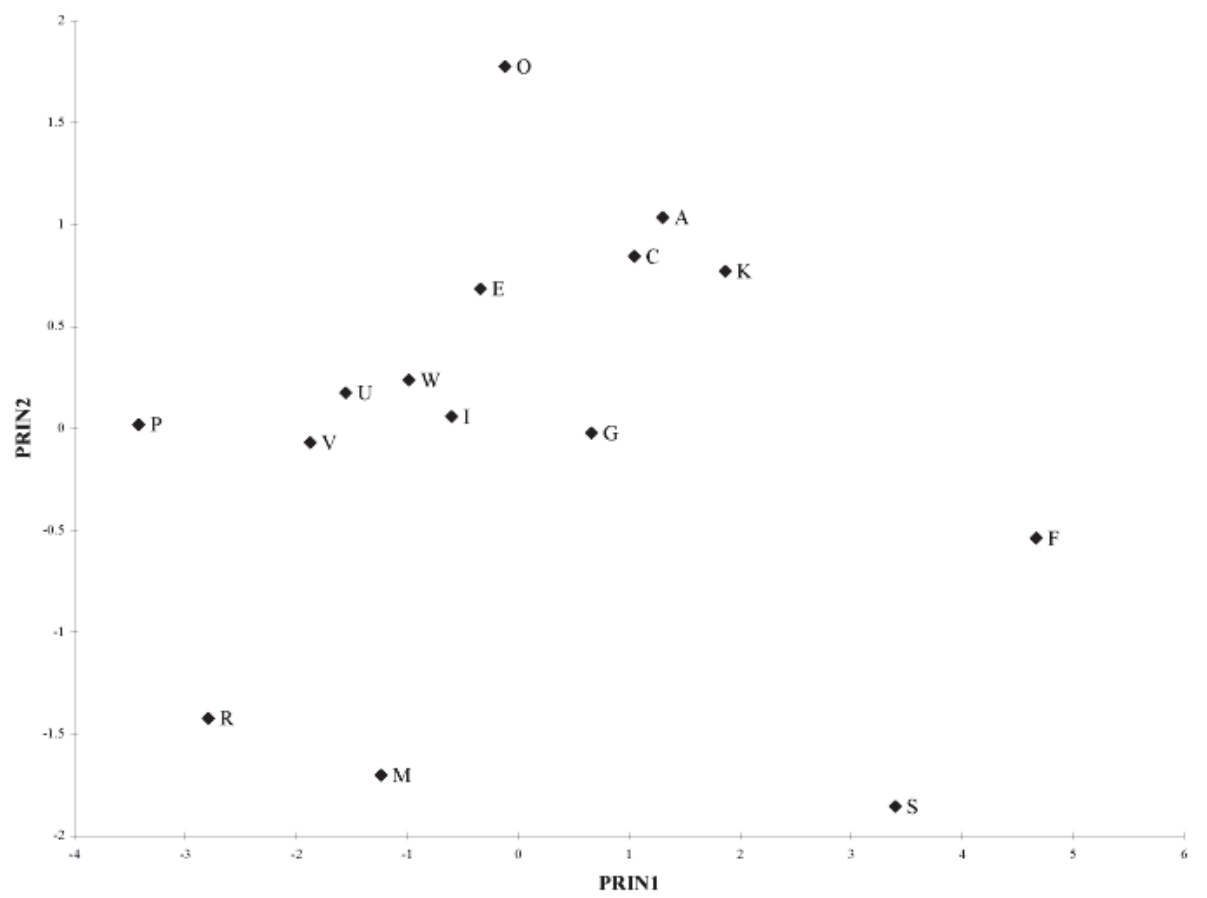

Fig. 2. Positions of Principal Component (PC) analysis scores for incipient injury temperature (IT) data of phloem-cambium tissue of two sweet cherries, 12 sour cherries, and one ground cherry on the first two PC axes. Abbreviations are as indicated in Table 1

linear combinations of the variables that contain most variability (Llorens et al., 2002; Rao, 1964). The PC analyses of xylem, cortical and vegetative bud tissue are not presented in this paper. The phloem-cambium and cortical tissues depicted gradations between minimum survival temperatures of the two presumed progenitor species of sour cherry; however, the gradations shown in the phloem-cambium tissue were of greatest interest. See Table
1 for the abbreviations representing the cultivars and seedlings on the PC analysis figure. In this study, in the analysis of the phloem-cambium tissue, the first two PCs of the phloem data account for $74 \%$ of the total variance among cultivar and seedling means; i.e., for $61 \%$ (PC1) and $13 \%$ of the variance (PC2), respectively (data not shown). Proceeding from negative to positive values of $\mathrm{PC} 1$, the cultivar and seedling means decrease in hardiness. The majority of separation of PC1 was due to differences among the selections for minimum hardiness values in October, December, January, and March. The sweet cherry and Hungarian selections are at the positive end of PC1 with positive values above 0 , while the selections derived from the colder regions of Germany and Moldavia have values $<0$. The variation of $\mathrm{PC} 2$ is due to differences in September and February (data not shown). Prunus fruticosa $(\mathrm{P})$ the presumed northern progenitor of sour cherry, and P. avium 'Emperor Francis' (F) the southern progenitor and 'Schmidt', are situated at the extremes of PC1, representing the extremes in their hardiness (Fig. 2 ). The $P$. cerasus cultivars and seedlings evaluated are situated between these two putative progenitors.

\section{Discussion}

The observation that LTEs occur in midwinter in the xylem of $P$. avium and P. cerasus is similar to that reported previously (Quamme et al., 1982; Rajashekar and Burke, 1978). In these above cited studies, the twigs LTEs in January were reported to occur between -37 and -41 ${ }^{\circ} \mathrm{C}$ for P. cerasus. Quamme et al. (1982) indicated lower temperatures for LTEs in $P$. avium than were found in my investigations. They reported LTE occurrences, on average at $-40.5^{\circ} \mathrm{C}$ for the taxon. My values were up to $18.5^{\circ} \mathrm{C}$ higher, but were more representative of the average minimum temperature isotherm at the northern geographic range of $P$. avium, $-29{ }^{\circ} \mathrm{C}$ (Quamme et al., 1982). The pattern of LTE occurrence was similar to that indicated by Wisniewski (1995): increasing in the fall, reaching a maximum in midwinter, and decreasing in the spring with LTEs absent in August, September, and October. Cells need to become thickened and rigid before they show supercooling characteristics. Nonrigid cells do not supercool (Rajashekar and Burke, 1996). During acclimation, cell walls typically become thicker, increase their tensile strength and decrease their pore sizes (Rajashekar and Lafta, 1996). Guak and Fuchigami (2001) speculated that short days and low temperatures or frosts regulate different and independent endogenous acclimation processes. Perhaps in August, September, and 
October sufficient short days but insufficient frosts have occurred to induce these changes.

The absence of LTEs in August, September, and October is also similar to the findings of Ketchie and Kammereck (1987) with Malus sp. (Mill.). Wisniewski et al. (1993) and Wisniewski (1995) noted that contact of the plasma membrane with the cell wall is essential for maximum supercooling to occur. In the early part of the season, contact may not be far enough progressed. Type, amount and degree of pectin cross-linking within the pit membrane have also been proven important in the occurrence of deep supercooling (Wisniewski, 1995) and offers a plausible explanation for seasonal shifts in occurrence. Perhaps there is not enough cross-linking established in August, September and October for supercooling to occur. Genetic variability in sour cherry, in this pectin-mediated regulation of the pit membrane, is very likely since there was variability in the size and occurrence of the LTE within the germplasm. Another explanation may be the exotherms were present, but the equipment used was unable to measure them during these three months. Ketchie and Kammerick (1987) speculated their lack of LTEs found in Malus in August, September and October might have been due to their equipment's inability to measure the exotherms.

The presence of a linear relationship between xylem browning and supercooling corresponds with the results of Hong and Sucoff (1982). The complexity of the LTE, found in my study, in terms of tissue correlation during acclimation, is similar to that indicated by Wisniewski (1995). Ashworth (1993) indicates that during acclimation, the complexity of shape of exotherms is accentuated. My observations concur. Ketchie and Kammerick (1987) indicate the number of exotherms is accentuated during acclimation. My observations agree with theirs. The correlation of the LTE with the phloem-cambium identified in November is consistent with the results of Ketchie and Kammerick (1987) where correlation of the LTE and xylem injury did not occur until maximum cold resistance had been obtained.

Wisniewski (1995) reported that the xylem in some species does not freeze in a homogeneous manner, but instead responds as a heterogeneous population of cells that freeze over a wide temperature range. From my observations, this is true for P. cerasus. During acclimation (November), browning injury preceded the LTE. During November, the DTA equipment was measuring some extracellular freezing or nonhomogeneous freezing which correlated best to the phloem-cambium. During maximum acclimation, December to February, browning occurred after the occurrence of the LTE and generally within $5^{\circ} \mathrm{C}$; this is in agreement with earlier reports (George et al., 1974).

Although average annual minimum temperature isotherms are often used to establish northern limits of distribution, the frequency of low temperature extremes and their distribution with respect to the acclimation and deacclimation cycles may be more critical in determining plant distribution. Significant differences in hardiness of the phloem-cambium existed between $P$. cerasus seedlings of northern origin compared to the industry standard, 'Montmorency', in late fall and early spring. These decreases in hardiness during acclimation and deacclimation may also affect plant distribution indirectly by increasing susceptibility to disease and insects. The phloem-cambium also expresses the most rapid deacclimation response. Because of the phloemcambium's susceptibility to cold injury during acclimation, the divergence of hardiness found between northern origin seedlings and 'Montmorency' and its rapid deacclimation response, it might be the most useful tissue in determining geographic distribution and commercial range.

The observation that supercooling occurs during the midwinter in xylem tissues of the majority of $P$. cerasus studied and that significant differences in LTE occurrence could be found between southern and northern genotypes implies that supercooling plays a critical part in survival and distribution of sour cherry. However, my studies only investigated temperature responses and other factors besides temperature such as daylength would likely influence distribution. The observation that supercooling limits $P$. cerasus germplasm distribution is similar to that made for other woody species in which supercooling also exists (George et al., 1974; Sakai, 1978).

DTA is useful for measuring the hardiness of the xylem in December to March in sour cherry, but it does not provide a measure of vegetative bud or phloem-cambium hardiness, both of which are considered to be more critical to survival than xylem hardiness (Quamme, 1991). Because of the strong correlation of xylem ITs to the LTEs (December to March) and the consistency of browning score occurrence (i.e., in all cultivars and seedlings), xylem ITs were the preferred method for evaluating the cold resistance of sour cherry in December to March in this study. Because of the strong correlation of phloem-cambium ITs to the LTE in November and the consistency of occurrence of the phloem browning scores vs. the LTEs, phloem-cambium ITs were preferred for November.

In the development of hardier $P$. cerasus cultivars, my study suggests that hardiness of the xylem and phloem-cambium can be increased through hybridization. Significant gains in hardiness over the industry standard, 'Montmorency', could be made in late fall and early spring. One conjecture regarding $P$. cerasus origin is that there were two putative progenitor species, $P$. avium and $P$. fruticosa. Following on this conjecture, it can be hypothesized that in an analysis of a P. cerasus germplasm one would expect to find a full range of $P$. cerasus with cold resistance levels similar to the cold tender $P$. avium to the cold tolerant $P$. fruticosa. Those $P$. cerasus exhibiting cold resistance similar to $P$. avium would predominantly have their origin in southern regions, whereas those similar to $P$. fruticosa, would have their origin in northern regions. Also, since 'Montmorency' is the standard cultivar in the P. cerasus industry, there would also be selections hardier than 'Montmorency' and selections less hardy than 'Montmorency.'

PC analysis was used to reveal common physiological (Tausz et al., 1998) or genetically inherited (Currie et al., 2000) principles in the data. This type of analysis assumes the presence of unobserved variables (PC factors) that underline the items or events originally measured (Tausz et al., 1998). The PC analysis of phloem-cambium supports the two putative progenitor species and southern, northern genotype hypothesis by the loading of minimum survival temperatures during acclimation and midwinter. Factor loading in the PC analysis can be interpreted as correlations between the variable (months) and components (Tausz et al., 1998). During these periods there are clear separations between northern and southern genotypes along the first PC axis. The results of the phloem-cambium PC analysis are particularly clear in support of the two putative progenitor species hypothesis and are of significance since the phloem-cambium was the least cold-tolerant tissue in the acclimation period and due to its correlation to the LTEs during this period. 


\section{Literature Cited}

Ashworth, E.N. 1993. Deep supercooling in woody plant tissues, p. 204-213. In: P.H. Li and L. Christersson (eds.). Advances in cold hardiness. CRS Press, Boca Raton, Fla.

Beaver, J.A. and A.F. Iezzoni. 1993. Allozyme inheritance in tetraploid sour cherry (Prunus cerasus L.). J. Amer. Soc. Hort. Sci. 118:873-877.

Cain, D.W. and R.L. Andersen. 1976. Sampling procedures for minimizing non-genetic wood hardiness variation in peach. J. Amer. Soc. Hort. Sci. 101:668-671.

Currie, A.J., S. Ganeshanandam, D.A. Noiton, D. Garrick, C.J.A. Shelbourne, and N. Oraguzie. 2000. Quantitative evaluation of apple (Malus $\mathrm{X}$ domestica Borkh.) fruit shape by principle component analysis of Fourier descriptors. Euphytica 111:219-227.

Gelvonauskis, B., P. Duchovskis, and G. Bandaraviciene. 2000. Investigation of winter hardiness and cold hardiness in apple progenies. Acta Hort. 538:277-280.

George, M.F., M.J. Burke, H.M. Pellet, and A.G. Johnson. 1974. Low temperature exotherms and woody plant distribution. HortScience 9:519-522.

Guak, S. and L.H. Fuchigami. 2001. Effects of applied ABA on growth cessation, bud dormancy, cold acclimation, leaf senescence and $\mathrm{N}$ mobilization in apple nursery plants. J. Hort. Sci. Biotechnol. 76:459-464.

Gusta, L.V., B.J. O'Conner, and M.G. MacHutcheon. 1997. The selection of superior winter-hardy genotypes using a prolonged freeze test. Can. J. Plant Sci. 77:15-21.

Hillig, K.W. and A.F. Iezzoni. 1988. Multivariate analysis of a sour cherry germplasm collection. J. Amer. Soc. Hort. Sci. 113:928-934.

Hong, S. and E. Sucoff. 1982. Rapid increase in deep supercooling of xylem parenchyma. Plant Physiol. 69:697-700.

Iezzoni, A.F. and M.P. Pritts. 1991. Applications of principal component analysis to horticultural research. HortScience 26:334-338.

Ketchie, D.O. and R. Kammereck. 1987. Seasonal variation of cold resistance in Malus woody tissue as determined by differential thermal analysis and viability tests. Can. J. Bot. 65:2640-2645.

Kovacs, L., G. DuGuoqiang, and D. Pinghai. 2002. Tissue moisture loss during sample preparation lowers exotherm temperatures in dormant grape buds. HortScience 37:701-704.

Llorens, L., X.Aranda,A. Abadia, and I. Fleck. 2002. Variations in Quercus ilex chloroplast pigment content during summer stress: Involvement in photoprotection according to principal component analysis. Funct. Plant Biol. 29:81-88.

Lo, M.H. and L.P. Abrahamson. 1996. Principal component analysis to evaluate the relative performance of nine year old hybrid poplar clones. Biomass Bioenergy 10:1-6.

Mathers, H.M., H.A. Quamme, and R.T. Brownlee. 1991. A procedure for converting an ultra-low temperature freezer for freezing biological material. Can. J. Plant Sci. 71:1281-1283.

McKenzie, J.S. and C.J. Weiser. 1975. Technique to inoculate woody plant stem sections with ice during artificial freezing. Can. J. Plant Sci. 55:651-653.

Quamme, H.A. 1991. Application of thermal analysis to breeding fruit crops for increased cold hardiness. HortScience 26:513-517.

Quamme, H.A. 1995. Deep supercooling in buds of woody plants, p. 183-199. In: R. Lee, G.J. Warren, and L.V. Gusta (eds.). Biological ice nucleation and its applications. APS Press, St. Paul, Minn.

Quamme, H.A., R.E.C. Layne, and W.G. Ronald. 1982. Relationship of supercooling to cold hardiness and the northern distribution of several cultivated and native Prunus species and hybrids. Can. J. Plant Sci. 62:137-148.

Rajashekar, C.B. and M.J. Burke. 1978. The occurrence of deep undercooling in the genera Pyrus, Prunus and Rosa: A preliminary report, p. 213-225. In: P.H. Li and A. Sakai (eds.) Plant cold hardiness and freezing stress. Academic, New York.

Rajashekar, C.B. and M.J. Burke. 1996. Freezing characteristics of rigid plant tissues, development of cell tension during extracellular freezing. Plant Physiol. 111:597-603.

Rajashekar, C.B. and A. Lafta. 1996. Cell wall changes and cell tension in response to cold acclimation and exogenous abscisic acid in leaves and cell cultures. Plant Physiol. 111:605-612.

Rao, C.R. 1964. The use and interpretation of principal component analysis in applied research, p. 329-358. In: P.C. Mahalanobsis and C.R. Rao (eds.). Sankhya the Indian journal of statistics, series A, vol. 26, part 4. Pergamon Press, New York.

Sakai, A. 1978. Freezing tolerance of evergreen and deciduous broadleaved trees in Japan with reference to tree regions, p. 1-19. In: Low Temp. Sci. Ser. B 36. Inst. of Low Temperature Sci., Hokkaido Univ., Japan.

Sakai, A. 1982. Freezing resistance of ornamental trees and shrubs. J. Amer. Soc. Hort. Sci. 107:572-581.

Sakai, A. 1978. Freezing tolerance of evergreen and deciduous broadleaved trees in Japan with reference to tree regions, p. 1-19. In: Low Temp. Sci. Ser. B 36. Inst. of Low Temperature Sci., Hokkaido Univ., Japan.

Sakai, A. and C. Weiser. 1973. Freezing resistance of trees. Ecology 54:118-126.

SAS Institute. 1989. SAS/STAT user's guide. Version 6, Vol. 2, 4th ed. SAS Inst., Cary, N.C.

Scientific Programming Enterprises. 1991. Plot-It user's guide. Version 2, Vol. 2. Scientific Programming Enterprises, Haslett, Mich.

Steel, R.G.D. and J.H. Torrie. 1980. Principles and procedures of statistics. 2nd ed. McGraw-Hill, New York.

Tausz M., M.S. Jimenez, and D. Grill. 1998. Antioxidative defence and photoprotection in pine needles under field conditions: A multivariate approach to evaluate patterns of physiological responses at natural sites. Physiologia Plantarum 104:760-764.

Wisniewski, M.E. 1995. Deep supercooling in woody plants and the role of cell wall structure, p. 163-179. In: R. Lee, G.J. Warren, and L.V. Gusta (eds.). Biological ice nucleation and its applications. APS Press, St. Paul, Minn.

Wisniewski, M.E., G. Davis, and R. Arora. 1993. Effect of macerase, oxalis acid, and EGTA on deep supercooling and pit membrane structure of xylem parenchyma of peach. Plant Physiol. 96:1354-1359.

Wisniewski, M.E., G. Lightner, G. Davis, and M. Schiavone. 1990. System configuration for micro-computer-controlled, low-temperature, differential thermal analysis. Comp. Elec. Agr. 5:223-230. 